\title{
Observations on the Occurrence of Subgenus Procamallanus (Spiro- camallanus) (Nematoda: Camallanidae) Parasitizing Two Species of Freshwater Fishes from Sindh, Pakistan
}

\author{
Muhammad Moosa Abro ${ }^{1 *}$, Nadir Ali Birmani² and Muhammad Bachal Bhutto ${ }^{3}$
}

${ }^{1}$ Department of Zoology, Government College University Hyderabad, Sindh, Pakistan; ${ }^{2}$ Department of Zoology, University of Sindh, Jamshoro, Pakistan; ${ }^{3}$ Department of Parasitology, Sindh Agriculture University, Tando Jam, Pakistan.

\begin{abstract}
Nematehelminthic examination of two species of freshwater fishes, Mastacembelus armatus and Oreochromis niloticus collected from the Indus river of Sindh Pakistan, revealed presence of subgenus Spirocamallanus of genus Procamallanus. The subgenus was characterized by the presence of spiral thickening in buccal capsule. The prevalence of subgenus was higher in Mastacembelus armatus (33.33\%) than Oreochromis niloticus (7.69\%). There is difference of mean intensity (3.66 and 4) and density (1.2 and 0.306) of Sprirocamallanus in both fishes. This subgenus is recorded for first time in Mastacembelus armatus and Oreochromis niloticus from the lower Indus river in Sindh province of Pakistan.

Received | December 05, 2020; Accepted | March 07, 2021; Published | May 15, 2021

*Correspondence | Muhammad Moosa Abro, Department of Zoology, Government College University Hyderabad, Sindh, Pakistan; Email: abromusa@gmail.com

Citation | Abro, M.M., N.A. Birmani and M.B. Bhutto. 2021. Observations on the occurrence of subgenus Procamallanus (Spirocamallanus) (Nematoda: Camallanidae) parasitizing two species of freshwater fishes from Sindh, Pakistan. Journal of Innovative Sciences, 7(1): 98-102.

DOI | https://dx.doi.org/10.17582/journal.jis/2021/7.1.98.102

Keywords | Procamallanus (Spirocamallanus), Mastacembelus armatus, Oreochromis niloticus, Indus river, Sindh, Pakistan
\end{abstract}

\section{Introduction}

Gubgenera of Procamallanus Baylis, 1923 including subgenus Spirocamallanus, consist of large number of species mainly recorded from tropical and subtropical marine water and freshwater fishes (Moravec and Van As, 2015). This genus was subdivided into five subgenera; Denticamallanus Moravec and Thatcher, 1997, Procamallanus Baylis, 1923, Punctocamallanus Moravec and Scholz, 1991, Spirocamallanoides Moravec and Sey, 1988 and Spirocamallanus Olsen, 1952 (Moravec and Thatcher, 1997) and Rigby and Rigby (2014) elevated the status of these subgenera to generic level. Many authors followed former subgeneric status and latter is dubbed as unnatural (Moravec and Van As, 2015). Moreover, the comparison of species on the basis of zoogeographic region have been accepted and preferred (Andrade-Salas et al., 1994; Rigby and Adamson, 1997; Rigby and Font, 1997). Many species of subgenus Procamallanus (Spirocamallanus) (many authors consider it genus in IndoPak region but this study considers it subgenus) recorded time to time from IndoPak subcontinent (Sood, 1989; Soota, 1983; Akhtar and Bilqees, 2011). Its morphological study needs organized and meticulous approach. The ecological parameters have been ignored in previous studies. The present paper provides general morphology and ecological study of subgenus Spirocammallanus recorded in Mastacembelus armatus and Oreochromis niolitcus from the Indus river. The subgenus under study previously recorded from marine and freshwater fishes including Tachysurus caelatus, Jhonius dussumeiri, Sillago sibama, Crossorhombus azureus, Argyrops spinifer, Otolithus argenteus, Otolithus ruber and Wallagu attu (Soota, 1983; Akhtar and Bilqees, 2011). 


\section{Material and Methods}

Eighteen specimens of Mastacembelus armatus and thirteen of Oreochromis niloticus were collected randomly with fixed fishing nets between April 2018 to January 2020 from the Indus river at Kotri barrage $25.4423^{\circ} \mathrm{N}, 68.3166^{\circ} \mathrm{E}$ and Sukkur barrage $27.6733^{\circ}$ $\mathrm{N}, 68.8471^{\circ}$ E. Both hosts collected from both localities. These localities are part of Sindh Province of Pakistan. Fish hosts were packed in plastic sacs and transported in ice box to Parasitology Laboratory, Department of Zoology, University of Sindh Jamshoro. Samples were dissected. Visceral organs were removed and placed separately in Petri plates. These organs were agitated and teased in normal saline. The visual and light microscopic observation noticed presence of nematodes in small intestine of some hosts. After collection of nematodes, they were preserved in $70 \%$ enthanol with few drops of glycerine. Semi-permanent slide was prepared for detail study on light microscopy. Photomicrographs were captured with Amscope trinocular microscope attached with 14 megapixel camera. Line drawings were made with drawing tube attached with Olympus microscope model Ch20i. All measurements taken in millimeter. Ecological parameters were followed as mentioned by Margolis et al. (1982) and Bush et al. (1997). Specimens were deposited in Zoology Museum, Department of Zoology, University of Sindh, Jamshoro.

\section{Result and Discussion}

A total of 26 specimens (16 male and 10 female) of subgenus Spirocamallanus were recorded from Mastacembelus armatus with prevalence of $33.33 \%$ and from Oreochromis niloticus with prevalence of $7.69 \%$.

\subsection{Description (Figures 1 and 2).}

Medium sized nematodes measured 4.38-5.1 X 0.140.21 with transversely striated cuticle. Mouth aperture circular. Buccal capsule prominent, thick walled, barrel shaped, slightly longer than wide, with well developed basal rings. Buccal capsule measured, 0.083-0.091 X 0.07-0.011. Inner surface of buccal capsule provided with 10-13 horizontal spiral ridges. Esophagus long and divided into short muscular and long glandular esophagus, muscular esophagus measured, 0.44-0.53 X0.06-0.09 and glandular esophagus measured 1-1.15 long. Both part of esophagus slightly expanded near their posterior ends. Posterior extremity of specimen bent ventrally, provided with alae and supported by ten pairs of pedunculated papillae. All papillae preanal in position. Spicule single, measured, 0.22-0.29 long, having stout gubernaculum measured $0.035-0.039$ in size.
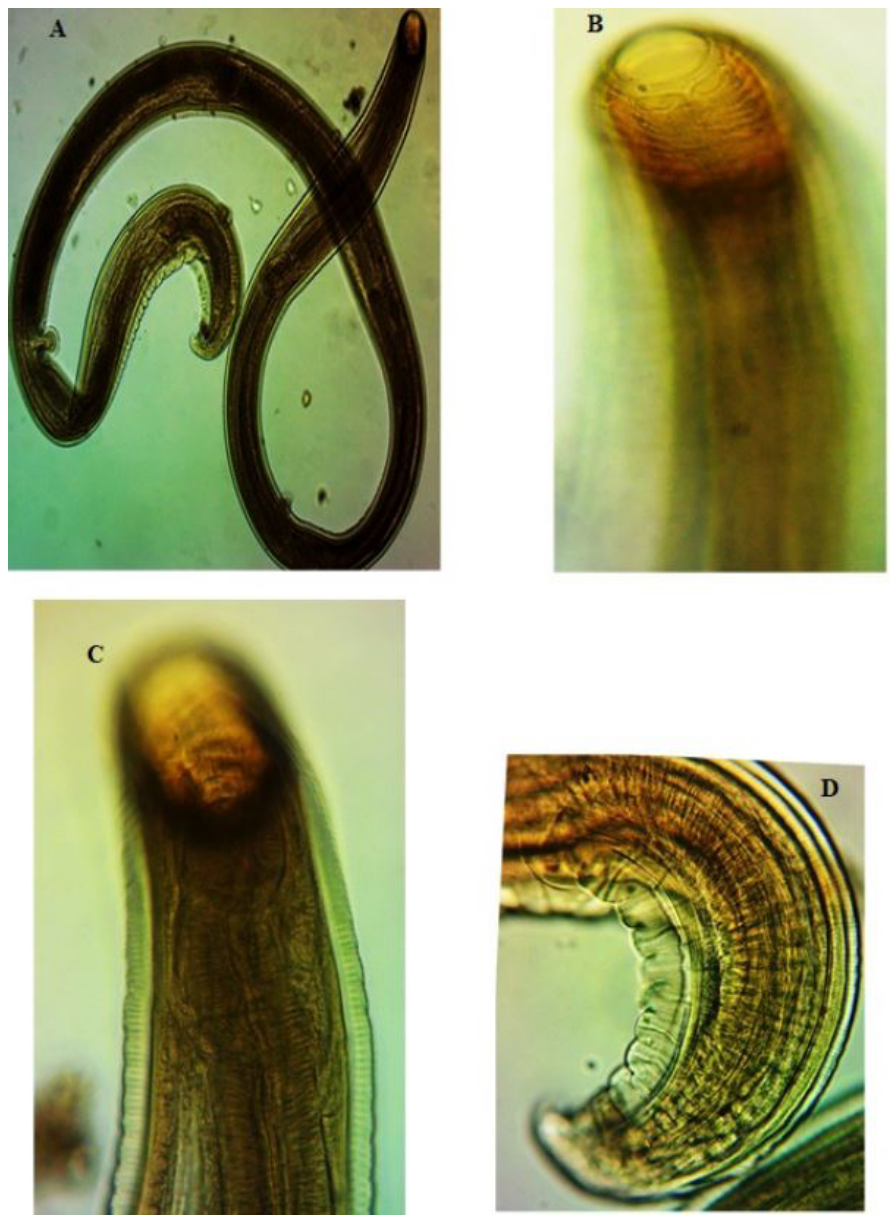

Figure 1: Procamallanus (Spirocamllanus) sp. A. Entire worm; B. Anterior extremity with buccal cavity; C. Anterior extremity with esophagus; D. Posterior extremity with spicule and Papillae.

Taxonomic summary

Family: Camallanidae Railliet and Henery, 1915

Genus: Procamallanus (Spirocamallanus) (Baylis, 1923)

Species: $\quad$ Procamallanus (Spirocamallanus) sp.

No. of speci- 26

mens collected:

Host:

Mastacembelus armatus (6/18), Oreochromis niloticus (1/13)

Prevalence: $\quad$ Mastacembelus armatus 33.33\%, Oreochromis niloticus $7.69 \%$

Site of infection: Intestine

Locality: Indus River at Sindh

Status: New host record 


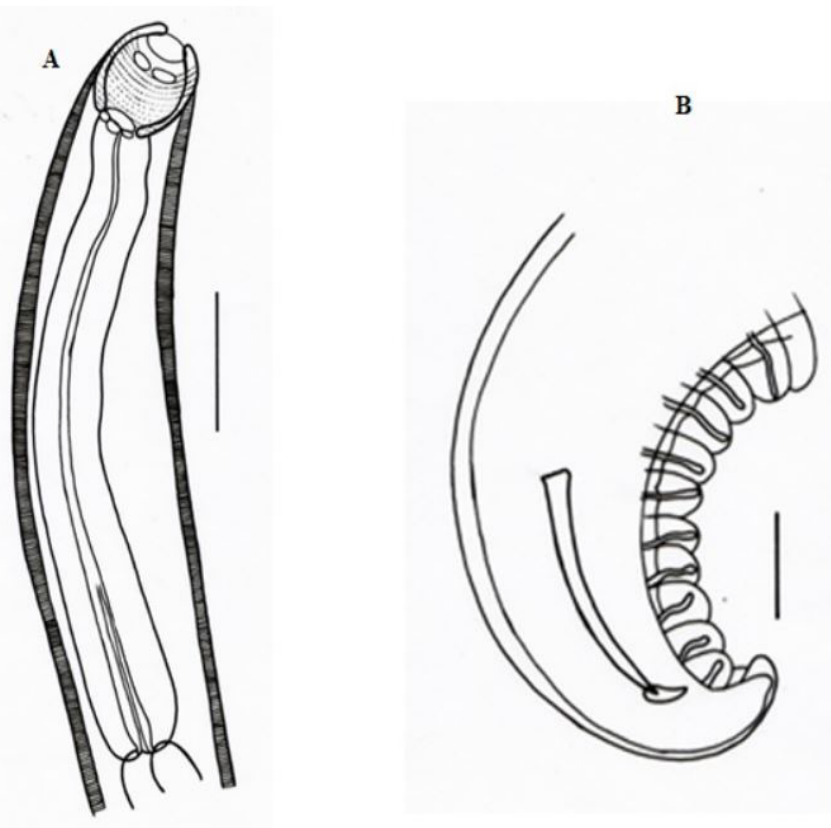

Figure 2: rocamallanus (Spirocamallanus) sp.A.Anterior extremity with buccal capsule and esophagus; B. Posterior extremity showing spicule and papillae. Scale Bar, A. 0.1 and B 0.5 mm

Present nematode morphologically belong to subgenus Procamallanus (Spirocammlanus) on basis of having spiral thickening in buccal capsule. This subgenus is previously reported from marine and freshwater fishes (Moravec and Van As, 2015). A good number of species reported from all over the world especially South Asia (Sood, 1989). Almost 10 species of subgenus Spirocamallanus recorded from Marine and freshwater fishes of Pakistan (Akhtar and Bilqees, 2011). Out of these, only few recorded from freshwater fishes including S. gubenaculus Khera, 1955 in Rita rita, Mystus cavasius, and Notopterus notopterus; S. kalaria Rehana and Bilqees, 1979 in Wallagu attu (Soota, 1983; Rehana and Bilqees, 1979).

Present study records this subgenus from two species of freshwater fishes from the Indus River.
Previous studies recorded Spirocammallanus and two other subgenera (Procamallanus Baylis, 1923 Denticamallanus Moravec and Thatcher, 1997) of genus Procamallanus from freshwater water fishes of Africa, South America, North America, Australia, Asia and Europe (Moravec et al., 2000,2019; Ramallo et al., 2017; Moravec and Scholz, 1991; Soota, 1983). A few study recorded species of Spirocamallanus from freshwater fishes of Pakistan (Rehana and Bilqees, 1979; Akhtar and Bilqees, 2011) and none has recorded this subgenus from Mastacembelus armatus and Oreochromis niloticus. Hence, it is first record of this nematode from hosts and locality.

The present study recorded 26 specimen of subgenus Spirocamallanus from Mastacembelus armatus and Oreochromis niloticus. Eighteen Mastacembelus armatus were examined 6 were found infected with 22 specimens of nematodes with prevalence (33.33\%), intensity (3.660 and density (1.2) recorded. Mastacembelus armatus eats diverse food including Prawn, earthworms, small fishes, small crabs, fish eggs, crustaceans, aquatic insect larvae (Ali et al., 2003; Sharifudin et al., 1998; Gupta and Baneerjee, 2016). Therefore, this fish may be infected due to its feeding habits. Thirteen Oreochromis niloticus were examined only one was harboring four specimens of Spirocamallanus with prevalence (7.69\%), intensity (4) and density (0.306). Oreochromis niloticus feeds on blue-green algae, aquatic invertebrates and plant materials (Getabu and Ngwala, 2014; Abari et al., 2015).

The difference in prevalence of Spirocamallanus in both host (Table 1) suggest that both host eat variety of diet and forage in different water area. Consequently, they face different environment factors. Moreover, life cycle of intermediate host and its being part of definitive host diet also determine prevalence of this nematode.

Table 1: Ecological parameters of Procamallanus (Spirocamallanus) population and feeding habits of host.

\begin{tabular}{|c|c|c|c|c|c|c|c|}
\hline Host & Diet & $\begin{array}{l}\text { Host ex- } \\
\text { amined }\end{array}$ & $\begin{array}{l}\text { Found } \\
\text { positive }\end{array}$ & $\begin{array}{l}\text { Recorded } \\
\text { Specimen }\end{array}$ & $\begin{array}{l}\text { Preva- } \\
\text { lence }\end{array}$ & $\begin{array}{l}\text { Mean } \\
\text { Intensity }\end{array}$ & $\begin{array}{l}\text { Relative } \\
\text { density }\end{array}$ \\
\hline $\begin{array}{l}\text { Masta- } \\
\text { cembelus } \\
\text { armatus }\end{array}$ & $\begin{array}{l}\text { Prawn, Earthworm, Small fish, small crabs, Molluscs, } \\
\text { Fish eggs (Ali et al., 2003), crustacean, forage fish, } \\
\text { annelids and aquatic insects (Sharifudin et al., 1998), } \\
\text { crustacean and insect larvae while the adults devour } \\
\text { small fish and tadpoles (Gupta, 2016) }\end{array}$ & 18 & 6 & 22 & $33.33 \%$ & 3.66 & 1.2 \\
\hline $\begin{array}{l}\text { Oreo- } \\
\text { chromis } \\
\text { niloticus }\end{array}$ & $\begin{array}{l}\text { Blue-green algae, Green algae, Diatoms, Desmids, } \\
\text { Aquatic invertebrates (Getabu and Abari, 2015) plant } \\
\text { materials (Ngwala, 2014) }\end{array}$ & 13 & 1 & 4 & $7.69 \%$ & 4 & 0.306 \\
\hline
\end{tabular}

Journal of Innovative Sciences

June 2021 | Volume 7 | Issue 1 | Page 100 
The intensity shows opposite view from prevalence (3.66 in Mastacembelus armatus and 4 in Oreochromis niloticus. Which is less diverse feeder than Mastacembelus armatus.

The relative density of Spirocamallanus (1.2 in Mastacembelus armatus and 0.306 in Oreochromis niloticus) reflects similarity with prevalence. Therefore, the higher prevalence and density of Spirocamallanus in Mastacembelus armatus than Oreochromis niloticus is either due to diverse feeding habits (Table 1) of Mastacembelus armatus, availability of intermediate host or preference of this nematode for this host. The running water in the river is suitable for Mastacembelus armatus than Oreochromis niloticus.

\section{Conclusions and Recommendations}

Subgenus Procamallanus (Spirocamallanus) was first time recorded from Mastacembelus armatus and Oreochromis niloticus from the Indus river at Sindh. This nematode found more prevalent in Mastacembelus armatus than Oreochromis niloticus.

\section{Acknowledgements}

This study part of HEC funded project 3426 NRPU /HEC. Authors acknowledges HEC efforts in this regard.

\section{Novelty Statement}

Current research paper recorded nematode, Procamallanus (Spirocamallanus) for first time from the two freshwater fishes species of the Indus river at Sindh.

\section{Author's Contribution}

Muhammad Moosa Abro and Nadir Ali Birmani conceived, designed and performed the experiments and wrote the paper. Muhammad Bachal Bhutto contributed reagents and analysis tools.

\section{Conflict of interest}

The authors have declared no conflict of interest.

\section{References}

Abari, M.A., Usman, M. and Yusuf, K., 2015. Food and feeding habit of Nile Tilapia
(Oreochromis niloticus) In Doma Dam, Nasarawa State, Nigeria. Production Agriculture and Technology 11(1): 67-74. ISSN: 0794-5213; Online copy available at www.patnsukjournal. net/currentissue

Akhtar, Y. and Bilqees, F.M., 2011. Description of Procamallanus (Spirocamallanus) ruberii n.sp. (Camallanidae Railliet and Henry, 1915) from marine fish Otolithus ruber (Sciaenidae) based on light and scanning electron microscopy. RADS Journal of Biological Research and Applied Science, 2(2): 1-6.

Ali, M.S., Rahman, M.M. Hossain L. and Mollah, M.F.A., 2003. Studies on the food habits of three species of Mastacembelidae. Bangladesh Journal of Fisheries Research, 7(1): 43-52.

Andrade-Salas, O., Pineda-Lo Pez R.F., and Garci A-Magan L.A., 1994. Spirocamallanus rebecae sp. n. (Nematoda: Camallanidae) from freshwater fishes in south-eastern Mexico. Folia Parasitologica, 41: 259-270.

Bush, O.A. Kevin, D.L., Jeffrey, M.L. and Allen, W.S., 1997. Parasitology meets ecology on its own terms: Margolis et al. Revisited. The Journal of Parasitology, 83(4): 575-583. https://doi. org/10.2307/3284227

Getabu, A. and Ngwala, 2014. A comparative study on the feeding habits of Oreochromis niloticus (Linnaeus) in Nyanza Gulf Lake Victoria and sewage fish ponds. Kenya Marine and Fisheries Research Institute Kisumu Laboratory P.O. Box 1881, Kisii.

Gupta, S. and Banerjee, S., 2016. Food, feeding habit and reproductive biology of Tire-track Spiny Eel (Mastacembelus armatus): A Review. Journal of Aquatic Resource Development, 7: 429. https://doi.org/10.4172/2155-9546.1000429

Margolis, L., Esch, G.W., Holmes, J.C., Kuris, A.M. and Schad, G.A., 1982. The use of ecological terms in parasitology (Report of an Ad Hoc Committee of the American Society of Parasitologists). The Journalof Parasitology, 68(1): 131-133. https://doi.org/10.2307/3281335

Moravec, F. and Scholz, T., 1991. Observations on some nematodes parasitic in freshwater fishes in Laos. Folia Parasitol (Praha), 38(2): 163-78. PMID: 1937275.

Moravec, F. and Van As, L., 2015. Procamallanus (Procamallanus) spp. (Nematoda: Camallanidae) in fishes of the Okavango River, Botswana, including the description of $P .(P$. 
pseudolaeviconchus n. sp. parasitic in Clarias spp. (Clariidae) from Botswana and Egypt. Systematic Parasitology, 90: 137-149. https:// doi.org/10.1007/s11230-014-9541-0

Moravec, F. and Thatcher, V.E., 1997. Procamallanus (Denticamallanus subgen. n.) dentatus n. sp. (Nematoda: Camallanidae) from the characid fish, Bryconops al-burnoides, in the Brazilian Amazon. Parasite, 4: 239-243. https://doi. org/10.1051/parasite/1997043239

Moravec, F., Salgado-Maldonado, G. and Juan, C., 2000. Three New Procamallanus (Spirocamallanus) Species from Freshwater Fishes in Mexico, Journal of Parasitology, 86(1): 119-127.

Moravec, F., Salgado-Maldonado, G. and Juan, C., 2019.Three new Procamallanus (Spirocamallanus) species from freshwater. Journal of Parasitology, 86(1): 119-127. https://doi.org/10.1645/00223395(2000)086[0119:TNPSSF]2.0.CO;2

Ngwala,J.J., 2014. Diet and feeding ecology of Nile Tilapia, Oreochromis Niloticus and Nile Perch, Lates Niloticus in protected and unprotected areas of Lake Victoria, Tanzania. International Journal of Scientific and Technology Research, 3: 11.

Rehana, R. and Bilqees, F.M., 1973. Procamallanus wallagus sp.n. (Nematoda: Camallanidae) from the fish Wallago attu of Sindh. Sindh University Research Journal, 7: 13-16.

Rigby, M.C. and Rigby, E., 2014. Order Camallanida: Super-families Anguillicoloidea and Camallanoidea. In: Schmidt- Rhaesa A. (Ed.) Handbook of Zoology - Gastrotricha, Cycloneuralia and Gnathifera. Vol. 2:
Nematoda. Berlin/ Boston: Walter De Gruyter GmbH, pp. 637-659.

Rigby, M.C. and Adamson, M.L., 1997. Spirocamallanus species French Polynesian coral reef fishes. Canadian Journal of Zoologie, 75: 1270-127. https://doi.org/10.1139/z97-150

Rigby, M.C. and Font, W.F., 1997. Redescription and range extension of Spirocamallanus istiblenni Noble, 1966 (Nematoda: Camallanidae) from coral reef fishes in the Pacific. Journal of the Helminthological Society of Washington, 64: 227223.

Rehana, R. and Bilqees, F.M., 1979. Three nematodes species of the genus Procamallanus Baylis, 1923 including two new species from the fishes of Kalri lake, Sind, Pakistan. Pakistan Journal of Zoology, 11: 281-293.

Ramallo,G.andAilan-Choke,L.,2017.Observations on two Procamallanus (Spirocamallanus) species (Nematoda: Camallanidae) from freshwater fishes in Argentina, including description of Procamallanus (Spirocamallanus) juana sp. nov. Zootaxa, 4323(2): 286-294. https://doi. org/10.11646/zootaxa.4323.2.12

Sherifudddin, M., Khan A.A. and Mustafa, S., 1998. Food and feeding habits of spiny eel, Mastacembelus armatus. Asian Fisheries Science, 11: 271-278.

Sood, M.L., 1989. Fish nematodes from South Asia, Kalyani Publishers, New Delhi.

Soota, T.D., 1983. Studies on nematode parasites of Indian vertebrates I. Fishes, records of zoological survey of India. Miscellaneous Publication occasional paper no. 54: 352. 